\title{
Non-recognition of Polygyny: Is It a Solution or an Opening of a Pandora's Box? - Some Lessons from South African Experience
}

\author{
Nqobizwe Mvelo Ngema
}

\begin{abstract}
This paper argues that non-recognition of polygyny is a product of ethnocentrism that permeated South Africa right from the advent of colonialism. The institution of Polygyny raised the eyebrows of both colonialists and missionaries immediately when it came to their attention and they started to treat it with distaste. Colonialists tried by all means to out root it from its core merely because it was not in line with their western morals, values and way of life. Ultimately, all customary marriages and religious marriages that are potentially polygamous were not recognized as valid marriages. This non-recognition proved to be detrimental to the rights and general welfare of women and children. Despite non-recognition of polygyny for more than sixty years in South Africa, Africans never stopped to practice it. As a result of this, the government of South Africa was forced by the circumstances to ultimately recognize it in order to avoid social ills that were created by non-recognition.
\end{abstract}

Index Terms-Polygyny, non-recognition, customary marriage and customary union.

\section{INTRODUCTION}

Marriage is a universal institution that is in sharp contrast with a relationship that is characterized by promiscuity and impermanence [1]. Marriage is further divided into monogamy and polygamy. Monogamy is where a men or woman is married to only one spouse. This type of marriage is more common in our contemporary society that highly disapproves a man to marry more than one wife. Moreover, economic problems and the life that is highly demanding make it difficult for a man to be able to support more than one wife. Polygamy is divided into polyandry and polygyny. Polyandry is where a woman is married to more than one husband at the same time while polygyny is where a man is married to more than one wife at the same time. The man that is married to more than one wife is regarded as a polygamist.

From the advent of colonialism in Africa, the institution of polygyny was condemned by colonialists together with the missionaries. Obviously, this is because of the general tendency towards ethnocentrism, whereby one group regards its values and beliefs as superior to others, while the other group holds firmly to indigenous practices which the former group regards as primitive rules for uncivilized barbarians [2]. Such prejudice can act as a barrier against social unity and harmonious co-existence of multiplicity of

Manuscript received February 5, 2015; revised August 23, 2015.

Nqobizwe Mvelo Ngema is with University of Zululand, South Africa (e-mail: ngemaNM@unizulu.ac.za). cultures in one society. This concern is clearly expressed in the following passage:

'South Africa is a country characterized by cultural and religious diversity. For this reason it has been described as multi-lingual, multi-faith, multi-cultural and multi-political country. The kaleidoscopic panorama of cultures, religions and languages is both strength and a weakness. While this cultural and religious pluralism adds to the [diversity] of the country, to enable these cultures, religions and languages to coexist harmoniously in one geographical territory is not an easy task. The reason for this [skepticism] is that these cultures and religions often clash. Although the differences may not be too great, people tend to exaggerate and accentuate the differences in order to justify preferential treatment for their own particular group. There is a streak in human nature which makes people feel better than others upon whom they look down [3].'

This situation was a matter of serious concern when the application of customary law became subject to repugnance by the ruling groups. The repugnancy clause provided that customary law would be applicable provided it was not clashing with the principles of public policy and natural justice. Hence the repugnancy clause subjected African customary law to European values and moral norms [4] to the detriment of African values, norms and belief system.

This imposition of European values and morals over African people appears in the adoption of the principle that was decided in the case of Hyde $v$ Hyde and another into South African Law. In the latter mentioned case it was held that marriage is 'the voluntary union for life of one man and one woman to the exclusion of all others'. This was a clear preference of nuclear family of an industrialized society to the detriment of an extended family of traditional society. Even though an extended family and values espoused by it was discouraged by the colonizers, it continues to serve a crucial role in securing for the aged, destitute and discouraging divorce [5]. Nuclear family lacked these advantages and is therefore prone to disintegrate more easily than the extended family. When a family disintegrates, society is adversely affected [6].

For a long period of time customary marriage was not treated as a valid marriage just because it permits polygyny while civil/Christian marriage was regarded as a valid marriage merely because it is monogamous in nature and embraces western morality and way of life. Hence polygyny was treated as contrary to public policy and natural justice. The decision of Hyde $v$ Hyde was adopted with approval to South African law by Judge CJ Inness in the case of 
Seedat's Executors v The Master (Natal) AD 1917. Inness CJ held that no country was under an obligation to recognize a legal relationship that was repugnant to moral principles of its people [7]. On the contrary, the Judge was not promoting moral principles of African people (that were the majority and still constitute the majority in South Africa) but clearly the European values and their sense of morality.

The aim of this paper is to argue that there is a lot that can be learned from the South African experience regarding the issue of non-recognition of polygyny. The following section would discuss that non-recognition inflicted more problems for women than intended good and it will reveal that it is easy to change the law than to change the society and peoples' perceptions.

\section{ILLS CREATED BY NON-RECOGNITION OF POLYGYNY IN SOUTH AFRICA}

It appears that from the advent of colonialism the custom of polygyny was treated as contrary to European sense of justice, morality and way of life. One of the colonialists during 1852-3 Natal Commission concluded that polygyny 'destroys all love between man and wife - it encourages war as a means of procuring cattle to pay for the panders to their lust and idleness; and by a fearful destruction of life, brings about an inequality of the sexes [8].'

Missionaries and colonialists treated polygyny as a heathen practice that is contrary to good morals and they tried by all means to out root it from its core. However, African people never succumbed to the negative attitude of the colonizers towards their customs and beliefs and they just continued with their custom of polygyny [9].

In 1883 the government of the Cape Colony made a thorough investigation of native laws and customs through the Commission and in doing so, it consulted a group of recognized experts in the field [10]. These experts were critical of customary marriage but their main intention was to harmonize customary law with western law and sense of morality and to protect the sanctity of marriage and the rights of women [11]. The report of the Cape Commission of 1883 on Native Law and Custom tolerated polygyny and was of the view that it was not necessary to abrogate polygyny merely because it was contrary to Christian faith and morality.

In a similar vein, the report of the 1903 South African Native Affairs Commission tolerated polygyny. The rationale for this toleration was that polygyny was a product of warfare and this delayed marriage for men who were warriors. This is so because traditionally, regiment that is still active in participating in wars is not allowed to get married until reaching a specific age. High mortality of males from warfare, disease, or dangerous occupations such as hunting created imbalances in sex ratio contributed to the popularity of polygyny. This tolerance was also based on the hope that when peace is attained, polygyny will fade away.

It is so unfortunate that the latter mentioned commissions never made any changes to policy formulation on the issue of polygyny and its recognition. Things were exacerbated by the promulgation of the Black Administration Act 38 of 1927 that permitted partial recognition to customary marriages in South Africa. This partial recognition of customary marriage is evident from the definition of a customary union in the Black Administration Act which stipulated that a customary union means 'the association of man and woman in a conjugal relationship according to Black law and custom, where neither the man nor the woman is party to a subsisting marriage.' On the other hand marriage was defined as meaning 'the union of one man with one woman in accordance with any law for the time being in force in any province governing marriages, but does not include any union contracted under Black law and custom or any union recognized as a marriage in Black law under the provisions of section one hundred and forty seven of the Natal and KwaZulu Codes.

In view of the above section, it appears clearly that the only marriage that was fully recognized as a legal marriage was a civil/Christian marriage. Customary union that was practiced by the majority of the South African citizens at that time was accorded partial recognition. Therefore customary union merely enjoyed full recognition for litigation purposes in traditional courts and commissioners courts [12] but not in magistrate court and Supreme Court. The irregularities flowing from the latter situation were exposed in actions instituted by dependents for the death of a breadwinner. If a dependent instituted a claim in the commissioners' court, there was a strong likelihood for his or her claim to succeed because customary union was fully recognized as a marriage before these courts. However, this depended much on the jurisdiction of the court, for example, in the case of Mokwena [13] that was decided in 1943; the claim for loss of support by the widow was held to disclose no cause of action because a customary union was not fully recognized as a marriage. In this case a defendant was a white person and therefore not subject to the jurisdiction of Commissioners Courts. These courts were designed to deal merely with customary law issues between black people only. As a result of this, the plaintiff's claim had to fail. The decision that was reached in Mokwena's case was later confirmed with approval by the Appellate Division judgment in the case of santam $v$ Fondo.

The above irregularity and injustice provoked legislative intervention during the 1960's. The legislature enacted the Black Laws Amendment Act 76 of 1963 in order to address the latter mentioned injustice and as a result of this, customary unions were recognized for claiming damages for the loss of support from any person who unlawfully causes the death of another partner. This legislative intervention never worked to the advantage of many women married in terms of customary law. This is so because of the technical requirement that required a woman who wanted to claim damages for loss of support to produce a certificate issued by a Commissioner. This frustrated many Black women because in reality many customary marriages were not registered and even today numerous customary marriages are not registered.

This non-recognition of polygyny in South Africa had a severe blow on the face of women practicing Islamic faith. A Muslim spouse could not be able to claim any damages for loss of support if his or her partner was unlawfully killed. The problem created by the non-recognition of polygyny is also evident in the case of Ismael v Ismael that was decided 
in 1983; the court refused to recognize the consequences of a polygamous marriage and concluded that Islamic marriage is contrary to good morals merely because it is potentially polygamous. Judge Trengove held that:

'The concept of marriage as a monogamous union is firmly entrenched in our society and the recognition of polygamy would undoubtedly tend to prejudice or undermine the status of marriage as we know it; and from a purely practical point of view it would, in my view, also be unwise to accord recognition to polygamous unions for the simple reason that all our marriage and family laws-and to some extent also our law of succession - are primarily designed for monogamous relationships.'

Judge Trengove asserted that a union may be regarded as contrary to good morals, if it is contrary to the accepted customs and usages which are regarded as morally binding upon all members of our society. This led to some interesting questions that were posed by Kerr [14]. He asks whether our society includes all inhabitants of South Africa or merely some and, if only some, which ones? If all inhabitants are included, however, how would monogamy be held to be "morally binding to all", since customary unions had been recognized for some years?

Another consequence of non-recognition of customary unions was the superseding effect given to a civil/Christian marriage. If a man married his first wife in terms of customary law and then marries another wife in terms of civil law, the second marriage automatically dissolved the first marriage. 'Husbands in particular had an easy method of ridding themselves of their wives without having to go through a regular divorce procedure [15].' On the contrary, if a spouse of a civil union intended to marry another person by customary rites, the second union would be invalid. This anomaly was addressed by the Marriage and Matrimonial Property Law Amendment Act 3 of 1988. The intention of the legislature was to give more protection for wives in customary marriage. As a result of the latter mentioned amendment, a customary marriage is no longer automatically terminated by a subsequent civil marriage.

Polygyny is now recognized in South Africa in terms of the Recognition of Customary Marriages Act 120 of 1998 that came into effect on 10 November 2000 and this was done in order to avoid the problems that were created by non-recognition. However, the Recognition Act imposed some requirements that must be adhered to in order for a polygamous marriage to be valid. The Recognition Act mandates the husband who intends to marry more than one wife to make an application to the high court for the approval of the matrimonial property system. This requirement imposed by the act is designed to harmonize the custom of polygyny with the ever growing popularity of the universality of human rights.

Be that as it may, the institution of polygyny is not free from challenges and problems associated with having more than one wife.

The following section intends to discuss that freedom of choice is part and parcel of human dignity and if a woman decides to marry a man that is already married and after considering all other relevant factors, she should be allowed to do so and that has nothing to do with the violation of her right to human dignity. South Africa realized that the non- recognition of polygyny brought many problems than intended good and ended up permitting it provided that it meets some requirements that are stipulated in the Recognition of Customary Marriages Act 120 of 1998.

\section{DIGNITY AND FREEDOM}

Dignity originates from religion, history and philosophy. [16] According to both Jewish and Christian faith all human beings are considered to have inherent worth because they are created in the image of God. Inherent worth is intrinsically possessed by virtue of being human. One need not possess any other qualification to enjoy inherent worth other than the fact that one is a human being. 'If all people have inherent worth regardless of their actions, capabilities or potential, then it is logical to assume that all people have equal worth.'[17]

Emmanuel Kant argued in his categorical imperative that people are not mere means to an end but are ends in themselves and should be treated accordingly. [18] In view of the Kantian categorical imperative Kant's main conclusion is that people have inner worth and autonomy and therefore they should be free to make their own choices. Autonomy is a further core component of human dignity and can be equated to freedom of choice. [19]

As argued before, polygyny constitutes differentiation between womxen and man, because only man has freedom to choose between having one wife or many wives while women have no such right. Now the question is whether such differentiation constitutes a violation of the right of women to human dignity or not. It has already been argued that dignity also incorporates freedom of choice. Women have the power to choose whether or not to be party to a polygamous relationship. A first wife could in theory protect herself by insisting on a civil marriage (that is monogamous in nature) or by refusing to consent to the subsequent customary marriages.

Be that as it may, yet it appears that the idea of free choice was challenged by the Gender Research Project and Women in Law in Southern Africa because it is not always realistic in practice. Factors such as unemployment, low paying jobs and discrimination perpetrated by patriarchy may leave females with no alternative but to consent to polygyny in order to survive. [20] In view of this, Dlamini argued that:

'It is hard to believe that a woman who decided freely to be involved in a customary marriage after taking all factors into account could be regarded as being discriminated against unfairly. If she entered into the marriage from her own free will and volition the state has no business in not recognizing that marriage on the ground that it makes her unequal to whomever...for some women it may sound hollow that their marriage is not recognized in order to make them equal with other women or men and to protect their dignity when in fact to attack their marriage is to affront their dignity. [21]'

This shows beyond any doubt that the abolition of polygyny is too controversial and this should be left to other forces and die its natural death as changing socio-economic conditions might lead to the inability of men to afford to 
marry and maintain more than one wife [22].

The following section intends to conclude the discussion on the question that has been posed earlier on, that is, is it a solution not to recognize polygyny or just an opening of a Pandora's Box that would be quite difficult to close or not? In an attempt to answer that question I relied on the South African experience.

\section{CONCLUSION}

Initially customary marriages were not fully recognized in South Africa just because they are polygamous in nature. This led to many unintended social problems. This paper concludes by arguing that the non-recognition of polygyny in South Africa had devastating effects on the rights and general welfare of many women under customary marriages The failure to recognize a marriage merely because it is potentially polygamous has no convincing justifications and this is just pure ethnocentrism that is inimical of cultural diversity. The failure to recognize polygamous marriages fails to acknowledge the reality that polygyny is an African tradition that has reasonable factors that led Africans to practice it in the first place. In addition to this, polygyny has not been taken away by any form of modernity and it persisted in South Africa for more than sixty years despite its vilification and non - recognition by colonizers and missionaries.

It is beyond any dispute that there are various responsibilities and challenges that are brought by polygyny, namely, additional children to the family, more emotional burden over the husband, additional extended family responsibilities and commitments, increased economic responsibility over the maintenance of the double marriages, increased sexual demand, additional accommodation and less private life for the man since his domestic duties have any doubt that the Constitution protects the rights of persons to choose freely anyone increased, strife between co-wives and the issue of human rights in a world that is shifting towards the universality of human rights. Be that as it may, monogamy does not seem to provide any better alternative. This is because there is no country in the world that prohibits pre-marital promiscuity and unmarried persons are free to have more than one lover. Therefore, there is no convincing justification of hindering a man who is honest and prepared to take full responsibility.

Moreover, polygamy continue to exist because of the support of some women and there is no justifiable ground for denying a woman the right to get married as a second wife if she has done so out of her own free will and volition and after considering all the factors that are involved in the process.

\section{REFERENCES}

[1] J. M. Cooper, "The early history of the family," Primitive Man, vol. 3 , p. 56,1930 .

[2] M. Pieterse, "It's a black thing: Upholding culture and customary law in a society founded on non-racialism," SAJHR, vol. 17, p. 366, 2001.

[3] C. R. M. Dlamini, "Culture, education and religion," Rights and Constitutionalism: The New South African Legal Order, p. 537, 1994

[4] Juma, "From repugnancy to the bill of rights: African customary law and human rights in Lesotho and South Africa," Speculum Juris, vol. $21 \mathrm{pp} \mathrm{88,2007.}$

[5] C. R. M. Dlamini, "The transformation of a customary marriage in Zulu law," CILSA, vol.16, pp. 384, 1983.

[6] C. R. M. Dlamini, "The role of customary law in meeting social needs," Acta Juridica, p. 75, 1991.

[7] C. R. M. Dlamini, "Recognition of customary marriage," De Rebus, p. 593, 1982.

[8] H. J. Simons, "The status of customary unions," Acta Juridica, pp. $17-19,1961$

[9] H. A. Junod, "Bantu marriage and Christian society," Bantu Studies, vol. 15 , pp. 30-31, 1941

[10] A. J. Kerr, "The cape government commission on native laws and customs," Transkei Law Journal, p. 11, 1986

[11] TW Bennett Sourcebook of African Customary Law for Southern Africa, p. 170, 1991

[12] A. J. Kerr, "Liability in Delict for wrongfully causing the death of a native man married according to native law," $S A L J$, vol. 73, pp. 402408, 1956

[13] C. R. M. Dlamini, "Claim by widow of customary union for loss of support," SALJ, p. 34, 1984.

[14] A. J. Kerr, "Back to the problems of a hundred or more years ago: public policy concerning contracts relating to marriages that are potentially or actually polygamous," SALJ, pp 445, 1984.

[15] C. Rautenbach, Introduction to Legal Pluralism, p. 172, 2010.

[16] C. McCrudden, "Human dignity and judicial interpretation of human rights," European Journal of International Law, p. 655, 2008.

[17] S. J. Fick, "Consenting to objectifying treatment? Human dignity and individual freedom," LLM Thesis, Faculty of Law, Stellenbosch University, South Africa, 2012.

[18] A. W. Wood, "What is Kantian ethics?" 2002, p. 163

[19] D. Bhana and M. Pieterse, "Towards a reconciliation of contract law and constitutional values: Brisley and afrox revisited," $S A L J$, p. 881 , 2005.

[20] S. E. Thompson, "Prostitution-a choice ignored," Women's Rights Law Reporter, p. 233, 2000

[21] C. R. M. Dlamini, "The ultimate recognition of the customary marriage in South Africa," Obiter, vol. 20, p. 25, 1999.

[22] C. Himonga et al., African Customary Law in South Africa PostApartheid and Living Law Perspective, 1st ed. Oxford University Press , Southern Africa, 2014, p.

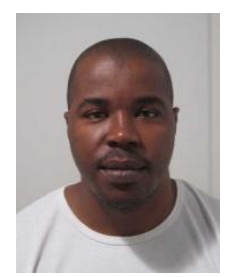

Nqobizwe Mvelo Ngema was born on September 9 1983 at Ulundi (Kwazulu-Natal province of South Africa). $\mathrm{He}$ is the lecturer at the University of Zululand (South Africa). He has the following academic qualifications: LLB (UNIZULU), LLM (UNISA), and certificate in postgraduate supervision (Rhodes University). He has nine years' lecturing experience and he has an interest in the field of human rights, constitutional law, public international law and customary law. He has published extensively in the field of customary law and human rights 